\title{
FAKTOR-FAKTOR YANG BERHUBUNGAN DENGAN TERJADINYA HIPERTENSI DALAM KEHAMILAN
}

\author{
R.Nur Abdurakhman*
}

\begin{abstract}
ABSTRAK
Berdasarkan studi pendahuluan yang telah dilakukan di Puskesmas Gunung Jati, data dari bulan Januari-Mei 2015 jumlah ibu hamil keseluruhan 313 orang, kasus ibu dengan hipertensi dalam kehamilan sebanyak 16 orang. Hipertensi dalam kehamilan merupakan peningkatan sistolik sebesar $30 \mathrm{mmHg}$ atau diastolic sebesar $15 \mathrm{mmHg}$ di atas nilai dasar tekanan darah. Penelitian ini bertujuan untuk mengetahuinya faktor-faktor yang mempengaruhi terjadinya hipertensi dalam kehamilan berdasarkan pengetahuan, usia ibu dan paritas di Puskesmas Gunung Jati Kabupaten Cirebon tahun 2015. Metode yang digunakan di dalam penelitian ini metode survey analitik dengan pendekatan cross secrtional. Jumlah sampel dalam penelitian ini sebanyak 76 responden. Data yang digunakan adalah data primer dan sekunder, pengumpulan data menggunakan kuesioner yang diberikan kepada responden. Analisa data pada penelitian ini menggunakan uji chi square. Hasil penelitian didapatkan 76 responden yang berusia $<20$ terdapat 8 orang $(10,5 \%)$, yang berusia 20-35 tahun terdapat 50 orang $(65,8 \%)$, dan yang berusia $>35$ tahun terdapat 18 orang $(23,7 \%)$. Responden berdasarkan tingkat pengetahuan dengan kriteria kurang berjumlah 19 orang (25\%), dengan kriteria cukup terdapat 37 orang $(48,7 \%)$, dan responden dengan kriteria baik terdapat 20 orang $(26,3 \%)$. Hasil uji didapatkan ada pengaruh faktor pengetahuan, factor umur, dan factor paritas terhadap terjadinya hipertensi dalam kehamilan.
\end{abstract}

Kata Kunci : Hipertensi Dalam Kehamilan, Pengetahuan, Umur, Paritas.

\begin{abstract}
Based on preliminary study that has been done at Puskesmas Gunung Jati, data from January to May 2015 the total number of pregnant women 313 people, cases of mothers with hypertension in pregnancy as many as 16 people. Hypertension in pregnancy is a $30 \mathrm{mmHg}$ or diastolic systolic increase of $15 \mathrm{mmHg}$ above the baseline blood pressure value. This study aims to find out the factors that influence the occurrence of hypertension in pregnancy based on knowledge, age and parity at Puskesmas Gunung Jati Cirebon Regency in 2015. The method used in this study analytical survey method with cross secrtional approach. The number of samples in this study were 76 respondents. The data used are primary and secondary data, data collection using questionnaires given to the respondents. Data analysis in this study using chi square test. The result of this research is 76 respondents aged $<20$, there are 8 people $(10,5 \%)$, aged $20-35$ years there are 50 people $(65,8 \%)$, and those aged $>35$ years there are 18 people $(23,7 \%)$. Respondents based on the level of knowledge with criteria of less 19 (25\%), with sufficient criteria there are 37 people (48.7\%), and respondents with good criteria there are 20 people $(26.3 \%)$. The test results obtained there is the influence of knowledge factor, age factor, and parity factor to the occurrence of hypertension in pregnancy.
\end{abstract}

Keywords: Hypertension in Pregnancy, Knowledge, Age, Parity.

*Staf Pengajar Program Studi S1 Keperawatan STIKes Cirebon 


\section{PENDAHULUAN}

Kehamilan adalah suatu proses alami yang didahului pertemuan ovum dan sperma yang disebut fertilisasi kemudian dilanjutkan lagi dengan nidasi dan implantasi sampai dengan janin dapat hidup dan berkembang di dunia luar. ${ }^{1}$

Setiap tahun sekitar 160 juta perempuan di seluruh dunia hamil. Sebagian besar kehamilan ini berlangsung aman. Namun, sekitar $15 \%$ menderita komplikasi berat, dengan sepertiganya merupakan komplikasi yang mengancam jiwa ibu. Komplikasi ini mengakibatkan kematian lebih dari setengah juta ibu setiap tahun. Dari jumlah ini diperkirakan $90 \%$ terjadi di Asia dan Afrika sub sahara, $10 \%$ di negara berkembang lainnya, dan kurang dari 1\% di negara-negara maju. Di beberapa negara risiko kematian ibu lebih tinggi dari 1 dalam 10 kehamilan, sedangkan di negara maju risiko ini kurang dari 1 dalam $6.000 .^{2}$ Diperkirakan dari setiap ibu meninggal dalam kehamilan, persalinan atau nifas, 16-17 ibu menderita komplikasi yang mempengaruhi kesehatan mereka, umumnya menetap. Penyebab utama kematian ibu yaitu perdarahan, infeksi, hipertensi dalam kehamilan, partus macet, dan aborsi. ${ }^{2}$ Hypertensi dalam kehamilan merupakan peningkatan sistolik sebesar $30 \mathrm{mmHg}$ atau diastolik sebesar 15 $\mathrm{mmHg}$ di atas nilai dasar tekanan darah. ${ }^{3}$

Berdasarkan studi pendahuluan yang peneliti lakukan di Puskesmas Gunung Jati, data dari bulan Januari-Mei 2015 jumlah ibu hamil keseluruhan 313 orang, kasus ibu dengan hipertensi dalam kehamilan sebanyak 16 orang. Berdasarkan kelompok usia ibu terdapat 9 ibu hamil yang mengalami hipertensi dalam kehamilan dengan usia 20-35 tahun, dan 7 ibu hamil yang mengalami hipertensi dalam kehamilan dengan usia $>35$ tahun. Berdasarkan jumlah paritas pada kelompok $\mathrm{P}=1$ terdapat 2 ibu hamil yang mengalami hipertensi, pada kelompok $\mathrm{M}=2-4$ terdapat 9 ibu hamil dengan hipertensi, dan pada kelompok $\mathrm{G}=>4$ terdapat 5 ibu hamil dengan hipertensi. Tujuan penelitian ini adalah untuk mengetahui faktorfaktor yang berhubungan dengan terjadinya hipertensi dalam kehamilan pada ibu hamil di Puskesmas Gunung Jati tahun 2015

\section{METODE PENELITIAN}

Penelitian adalah upaya untuk memahami dan memecahkan masalah secara ilmiah, sistematika dan logis, yang mana di dalam penelitian ini menggunakan metode survey analitik dengan pendekatan "cross sectional" yaitu data yang dikumpulkan sesaat atau data diperoleh saat ini juga. Cara ini dilakukan dengan melakukan survey, wawancara, atau dengan menyebar kuesioner pada responden penelitian. ${ }^{4}$ Pada penelitian ini variabel independen yang diteliti adalah pengetahuan, umur, paritas sedangkan variabel dependen adalah kasus hipertensi dalam kehamilan. Populasi pada penelitian ini adalah semua ibu hamil yang berada di wilayah kerja Puskesmas Gunung Jati pada bulan Juni-September 2015 berjumlah 313 orang ibu hamil. Teknik pengambilan sampelnya yaitu dengan cara accidental sampling dilakukan dengan mengambil kasus atau responden yang kebetulan ada atau tersedia disuatu tempat sesuai dengan konteks penelitian. jumlah sampel bejumlah 76 orang. Analisa data menggunakan uji chi square.

\section{HASIL PENELITIAN Pengetahuan}

Tabel 1. Distribusi Frekuensi Responden Berdasarkan Faktor Pengetahuan

\begin{tabular}{ccc}
\hline Pengetahuan & Jumlah & Persentase (\%) \\
\hline Baik & 20 & 26,3 \\
Cukup & 37 & 48,7 \\
Kurang & 19 & 25 \\
\hline Jumlah & 76 & 100 \\
\hline
\end{tabular}


Berdasarkan tabel 1. sebagian besar responden berpengetahuan kurang yaitu sebanyak 19 responden (25\%). Untuk pengetahuan yang cukup yaitu sebanyak 37 responden $(48,7 \%)$. Untuk pengetahuan yang baik yaitu sebanyak 20 orang responden $(26,3 \%)$.

\section{Umur}

Tabel 2. Distribusi Frekuensi Responden Berdasarkan Faktor Umur

\begin{tabular}{ccc}
\hline Umur & Jumlah & Persentase $(\%)$ \\
\hline$<20$ tahun & 8 & 10,5 \\
$20-35$ tahun & 50 & 65,8 \\
$>35$ tahun & 18 & 23,7 \\
\hline Jumlah & 76 & 100 \\
\hline
\end{tabular}

Berdasarkan tabel 2 sebagian besar responden berada pada kelompok umur 20-35 tahun sebanyak 50 responden $(65,8 \%)$ sedangkan pada kelompok umur $<20$ tahun ada 8 responden $(10,5 \%)$. Dan pada kelompok umur $>35$ tahun ada 18 responden $(23,7 \%)$.

\section{Paritas}

Tabel 3. Distribusi Frekuensi Responden Berdasarkan Faktor Paritas

\begin{tabular}{ccc}
\hline Paritas & Jumlah & Persentase (\%) \\
\hline $\mathrm{P}=1$ & 20 & 26,3 \\
$\mathrm{M}=2-4$ & 45 & 59,2 \\
$\mathrm{G}=>4$ & 11 & 14,5 \\
\hline Jumlah & 76 & 100 \\
\hline
\end{tabular}

Berdasarkan tabel 3 faktor paritas yang paling tinggi terdapat pada multigravida (2-4) dengan jumlah 47 responden $(59,2 \%)$ sedangkan pada grandemulti (> 4) jumlah keseluruhan ada 11 responden yang hipertensi dengan persentasi $(14,5 \%)$ dan pada primigravida berjumlah 20 responden $(26,3 \%)$.

\section{Pengaruh Pengetahuan Terhadap Kejadian Hipertensi Dalam Kehamilan}

Tabel 4. Pengaruh Pengetahuan Terhadap kejadian Hipertensi

\begin{tabular}{|c|c|c|c|c|c|c|}
\hline \multirow{3}{*}{ Pengetahuan } & \multicolumn{4}{|c|}{ Hipertensi } & \multirow{3}{*}{ Jumlah } & \multirow{3}{*}{$\begin{array}{c}P \\
\text { Value }\end{array}$} \\
\hline & \multicolumn{2}{|c|}{$\mathrm{Ya}$} & \multicolumn{2}{|c|}{ Tidak } & & \\
\hline & $\mathrm{n}$ & $\%$ & $\mathrm{n}$ & $\%$ & & \\
\hline Baik & 2 & 10 & 18 & 90 & 20 & \multirow{4}{*}{0,029} \\
\hline Cukup & 6 & 16,2 & 31 & 83,8 & 37 & \\
\hline Kurang & 8 & 42 & 11 & 58 & 19 & \\
\hline Jumlah & 16 & & 60 & & 76 & \\
\hline
\end{tabular}

Dari data tabel 4 pada kelompok pengetahuan dengan kategori baik terdapat 2 responden dengan hipertensi, sedangkan pada kelompok pengetahuan cukup terdapat 6 responden dengan hipertensi dan pada kelompok pengetahuan kurang terdapat 8 responden dengan hipertensi. Dari hasil penghitungan uji chi-square maka didapat hasil nilai p-value yaitu $0,029<0,1$. Maka Ho ditolak dan Ha diterima, artinya ada hubungan antara pengetahuan dengan terjadinya kasus hipertensi di Puskesmas Gunung Jati tahun 2015. 


\section{Pengaruh Umur Terhadap Kejadian Hipertensi Dalam Kehamilan}

Tabel 5. Pengaruh Umur Terhadap kejadian Hipertensi

\begin{tabular}{|c|c|c|c|c|c|c|}
\hline \multirow{3}{*}{ Umur } & \multicolumn{4}{|c|}{ Hipertensi } & \multirow{3}{*}{ Jumlah } & \multirow{3}{*}{$\begin{array}{c}P \\
\text { Value }\end{array}$} \\
\hline & \multicolumn{2}{|c|}{$\mathrm{Ya}$} & \multicolumn{2}{|c|}{ Tidak } & & \\
\hline & $\mathrm{n}$ & $\%$ & $\mathrm{n}$ & $\%$ & & \\
\hline$<20$ & 0 & 0 & 8 & 100 & 8 & \\
\hline $20-35$ & 9 & 18 & 41 & 82 & 50 & \\
\hline$>35$ & 7 & 39 & 11 & 61 & 18 & 0,053 \\
\hline Jumlah & 16 & & 60 & & 76 & \\
\hline
\end{tabular}

Dari data tabel 5 pada kelompok umur 20-35 tahun terdapat 12 responden dengan hipertensi, sedangkan kelompok umur $<20$ tahun tidak terdapat responden dengan hipertensi dan pada kelompok umur $>35$ tahun ada 4 responden dengan hipertensi.

Dari hasil penghitungan chi-square didapat hasil nilai $p$-value yaitu $0,053<0,1$. Maka Ho di tolak dan Ha diterima, artinya ada hubungan antara umur dengan terjadinya kasus hipertensi di Puskesmas Gunung Jati tahun 2015.

\section{Pengaruh Paritas Terhadap Kejadian Hipertensi}

Tabel 6. Pengaruh Paritas Terhadap kejadian Hipertensi

\begin{tabular}{|c|c|c|c|c|c|c|}
\hline \multirow{3}{*}{ Paritas } & \multicolumn{4}{|c|}{ Hipertensi } & \multirow{3}{*}{ Jumlah } & \multirow{3}{*}{$\begin{array}{c}\mathrm{P} \\
\text { Value }\end{array}$} \\
\hline & \multicolumn{2}{|c|}{$\mathrm{Ya}$} & \multicolumn{2}{|c|}{ Tidak } & & \\
\hline & $\mathrm{n}$ & $\%$ & $\mathrm{n}$ & $\%$ & & \\
\hline $\mathrm{P}=1$ & 2 & 10 & 18 & 90 & 20 & \\
\hline$M=2-4$ & 9 & 20 & 36 & 80 & 45 & \\
\hline $\mathrm{G}=>4$ & 5 & 45,5 & 6 & 54,5 & 11 & 0,065 \\
\hline Jumlah & 16 & & 60 & & 76 & \\
\hline
\end{tabular}

Dari data tabel 6 pada kelompok paritas primi $=1$ terdapat 2 responden dengan hipertensi, sedangkan kelompok paritas multi $=2-4$ terdapat 9 responden dengan hipertensi dan pada paritas grande $=>4$ terdapat 5 responden dengan hipertensi. Dari hasil penghitungan chisquare didapat hasil nilai p-value yaitu $0,065<0,1$. Maka Ho ditolak dan Ha diterima, artinya ada hubungan antara paritas dengan terjadinya kasus hipertensi di Puskesmas Gunung Jati Tahun 2015.

\section{PEMBAHASAN}

\section{Pengetahuan}

Berdasarkan hasil penelitian yang dilakukan di Puskesmas Gunung Jati tahun 2015, distribusi frekuensi berdasarkan status pendidikan hasilnya sebagian besar responden berpengetahuan kurang yaitu sebanyak 19 responden, 8 responden yang mengalami hipertensi dan yang tidak hipertensi 11 responden.

Pengetahuan adalah kesan di dalam pikiran manusia sebagai hasil penggunaan panca inderanya. Pengetahuan sangat berbeda dengan kepercayaan (beliefs), takhayul (superstition), dan penerangan-penerangan yang keliru (misinformation). Pengetahuan adalah segala apa yang diketahui berdasarkan pengalaman yang didapatkan oleh setiap manusia. ${ }^{5}$

Pengetahuan yang termasuk ke dalam domain kognitif mempunyai enam tingkatan:

a) Tahu (know)

b) Memahami (comprehension) 
c) Aplikasi (application)

d) Analisis (analysis)

e) Sintesis (synthesis)

f) Evaluasi (evaluation)

Pengetahuan ibu sangat mempengaruhi terjadinya hipertensi dalam kehamilan. Ibu yang berpengetahuan rendah memiliki kemungkinan lebih besar mengalami hipertensi dalam kehamilan dari pada ibu yang berpengetahuan tinggi karena ia tidak mengetahui tanda gejala hipertensi dan manfaat pemeriksaan yang dilakukan oleh tenaga kesehatan. ${ }^{5}$

\section{Umur}

Distribusi frekuensi berdasarkan umur didapatkan hasil sebagian besar responden ibu hamil berada pada kelompok umur 20-35 tahun sebanyak 52 responden, yang mengalami hipertensi ada 12 responden dan 40 responden yang tidak hipertensi.

Usia ibu sangat berpengaruh terhadap proses reproduksi. Dalam kurun waktu reproduksi sehat diketahui bahwa usia yang aman untuk kehamilan dan persalinan adalah usia 20-35 tahun, dimana organ reproduksi sudah sempurna dalam menjalani fungsinya. ${ }^{6}$

Ibu yang bersalin dengan partus lama yang disebabkan oleh kelainan his biasanya disebabkan oleh faktor usia yang relatif tua, terutama jika ia berusia lebih dari 35 tahun. $^{7}$

\section{Paritas}

Distribusi frekuensi berdasarkan paritas didapatkan hasil, sebagian besar responden berada pada kelompok paritas multigravida (2-4) dengan jumlah 47 responden, yang hipertensi ada 11 responden dan yang tidak hipertensi ada 36 responden. Paritas 2-3 merupakan paritas paling aman ditinjau dari sudut kematian maternal.

Paritas 2-3 merupakan paritas paling aman ditinjau dari sudut kematian maternal. Lebih tinggi paritas (lebih dari 3), lebih tinggi kematian maternal. Risiko pada paritas tinggi dapat dikurangi atau dicegah dengan keluarga berencana. Sebagian kehamilan pada paritas tinggi adalah tidak direncanakan. ${ }^{8}$

\section{Pengaruh pengetahuan ibu hamil terhadap hipertensi dalam kehamilan di Puskesmas Gunung Jati tahun 2015.}

Berdasarkan hasil penelitian di atas yang dilakukan di wilayah kerja Puskesmas Gunung Jati ternyata masih ada responden yang pengetahuannya cukup yaitu sebanyak terdapat 6 orang dengan hipertensi dalam kehamilan dan pada kelompok pengetahuan kurang terdapat 8 responden dengan hipertensi dalam kehamilan. Sehingga didapat hasil nilai p value yaitu $0,029<0,1$. Maka Ho ditolak dan Ha diterima, artinya ada hubungan yang bermakna antara pengetahuan dengan terjadinya kasus hipertensi dalam kehamilan di Puskesmas Gunung Jati tahun 2015.

Ibu yang berpengetahuan rendah memiliki kemungkinan lebih besar mengalami hipertensi dalam kehamilan pada kehamilan dari pada ibu yang berpengetahun tinggi karena ia tidak mengetahui tanda gejala hipertensi dalam kehamilan dan manfaat pemeriksaan yang dilakukan oleh tenaga kesehatan. ${ }^{9}$

Oleh sebab itu, petugas kesehatan harus meningkatkan pengetahuan dan wawasan ibu hamil yang hipertensi dalam kehamilan maupun yang tidak hipertensi dalam kehamilan tentang pengetahuan tanda-tanda terjadinya hipertensi dalam kehamilan yaitu dengan cara diadakannya penyuluhan/konseling, memberikan informasi melalui kegiatan posyandu untuk menekan angka kejadian hipertensi dalam kehamilan. 


\section{Pengaruh umur ibu hamil terhadap hipertensi dalam kehamilan di Puskesmas Gunung Jati tahun 2015.}

Berdasarkan hasil penelitian di atas yang dilakukan di wilayah kerja Puskesmas Gunung Jati untuk kategori umur 20-35 tahun terdapat 9 responden dengan hipertensi dalam kehamilan, sedangkan kelompok umur $<20$ tahun tidak terdapat responden dengan hipertensi dalam kehamilan dan pada kelompok umur $>35$ tahun ada 7 responden dengan hipertensi dalam kehamilan.

Dari hasil analisis antara umur ibu dengan kejadian hipertensi dalam kehamilan dapat disimpulkan bahwa kejadian paling tinggi untuk kasus hipertensi dalam kehamilan adalah pada umur 20-35 tahun. Dari hasil uji statistik di dapatkan nilai $p$-value $=0,053<0,1$ yang berarti Ho ditolak Ha diterima artinya ada hubungan yang bermakna antara umur ibu dengan meningkatnya kasus hipertensi dalam kehamilan.

Oleh sebab itu, petugas kesehatan harus memberikan informasi kepada semua ibu hamil baik yang hipertensi dalam kehamilan maupun yang tidak hipertensi dalam kehamilan bahwa di usia ibu hamil yang 20-35 tahun juga ternyata berisiko terkena gangguan kehamilan, apalagi yang >35 tahun akan lebih berisiko terjadinya gangguan-gangguan kehamilan, maka dari itu harus dilakukan konseling atau penyuluhan kepada semua ibu hamil supaya bisa memeriksakan kehamilannya secara rutin ke tenaga kesehatan serta memberikan penyuluhan kepada ibu hamil yang usianya di atas 35 tahun misalnya penyuluhan tentang kontrasepsi KB untuk menjarangkan kehamilan.

\section{Pengaruh paritas ibu hamil terhadap hipertensi dalam kehamilan di Puskesmas Gunung Jati tahun 2015.}

Berdasarkan hasil penelitian di atas yang dilakukan di wilayah kerja Puskesmas Gunung Jati, untuk kategori paritas primi $=1$ terdapat 2 responden dengan hipertensi dalam kehamilan, sedangkan kelompok paritas multi $=2-4$ terdapat 9 responden dengan hipertensi dalam kehamilan dan pada paritas grande $=>4$ terdapat 5 responden dengan hipertensi dalam kehamilan. Sehingga dari hasil uji statistik di dapatkan nilai $p$-value $=0,065<0,1$ yang berarti Ho ditolak dan $\mathrm{Ha}$ diterima. Artinya ada hubungan antara paritas ibu dengan meningkatnya kasus hipertensi.

Dan ternyata bukan hanya pada grandemulti saja yang beresiko pada multigravida juga akan berisiko terjadinya komplikasi kehamilan karena menurut hasil penelitian paling banyak ibu hamil yang hipertensi pada kategori multigravida berjumlah 9 orang.

Oleh sebab itu disarankan untuk petugas kesehatan supaya lebih waspada terhadap paritas dengan jumlah 2 kali atau kelahiran lebih dari 4, yaitu dengan cara memberikan konseling tentang kontrasepsi keluarga berencana untuk menjarangkan ataupun menunda kehamilan. Karena menurut teori kelahiran lebih dari 4 kali akan beresiko lebih tinggi terjadinya gangguan-gangguan kehamilan.

\section{SIMPULAN}

1. Pengaruh pengetahuan ibu hamil terhadap hipertensi dalam kehamilan di Puskesmas Gunung Jati tahun 2015, diperoleh nilai $p$ value $0,029<0,1$ maka dengan demikian Ho ditolak dan Ha diterima, artinya ada pengaruh antara pengetahuan dengan terjadinya hipertensi dalam kehamilan.

2. Pengaruh umur ibu hamil terhadap hipertensi dalam kehamilan di Puskesmas Gunung Jati tahun 2015, diperoleh nilai $p$ value $0,053<0,1$ maka dengan demikian Ho ditolak dan Ha diterima, artinya ada pengaruh antara umur dengan terjadinya hipertensi dalam kehamilan.

3. Pengaruh paritas ibu hamil terhadap hipertensi dalam kehamilan di Puskesmas Gunung Jati tahun 2015, diperoleh nilai $p$ value $0,065<0,1$ maka dengan demikian Ho ditolak, artinya ada pengaruh antara paritas dengan terjadinya hipertensi dalam kehamilan. 


\section{SARAN}

\section{Bagi peneliti selanjutnya}

Diharapkan Karya Tulis Ilmiah ini dapat menjadi bahan acuan atau referensi bagi peneliti selanjutnya untuk melakukan penelitian, terutama mengenai tanda-tanda terjadinya hipertensi dalam kehamilan.

\section{Bagi Responden}

1. Bagi responden sendiri diharapkan bisa menambah wawasan serta mengetahui informasi tentang tanda-tanda terjadinya hipertensi dalam kehamilan.

2. Diharapkan bagi responden untuk hamil di usia produktif untuk menghindari penyulit dalam kehamilan.

3. Diharapkan bagi responden untuk ikut berpartisipasi dalam program Keluarga Berencana (KB) sebagai upaya untuk menjarangkan kehamilan.

4. Diharapkan bagi responden untuk selalu memeriksakan kehamilannya secara rutin ke tenaga kesehatan sesuai ketentuan.

\section{Bagi Puskesmas Gunung Jati}

1. Dari hasil penelitian yang telah saya lakukan diperoleh hasil bahwa terdapat pengaruh antara pengetahuan terhadap kejadian hipertensi dalam kehamilan di Wilayah Kerja Puskesmas Gunung Jati tahun 2015, maka diperlukan adanya penyuluhan atau konseling kepada ibu hamil baik yang mempunyai hipertensi dalam kehamilan maupun yang tidak mempunyai hipertensi dalam kehamilan sehingga bisa menambah wawasan yang baik bagi ibu hamil.

2. Dari hasil penelitian yang telah dilakukan di Puskesmas Gunung Jati diperoleh hasil bahwa terdapat pengaruh umur terhadap kejadian hipertensi dalam kehamilan di Wilayah Kerja Puskesmas Gunung Jati tahun 2015, maka disarankan untuk para petugas di Puskesmas Gunung Jati lebih meningkatkan dalam sistem pendokumentasian khususnya pencatatan kohort ibu, pengisian buku KIA dan pengisian Kartu ibu agar ibu hamil yang berada di Wilayah kerja Puskesmas Gunung Jati dapat teregistrasi sehingga tahu ibu hamil mana yang masuk ke golongan risiko tinggi.

3. Dari hasil penelitian yang telah dilakukan di Puskesmas Gunung Jati diperoleh hasil bahwa terdapat pengaruh paritas terhadap kejadian hipertensi dalam kehamilan di Wilayah Kerja Puskesmas Gunung Jati tahun 2015, maka disarankan untuk para petugas di Puskesmas Gunung Jati lebih meningkatkan dalam pendokumentasian dan penyuluhan atau konseling tentang keluarga berencana yang tujuannya untuk menjarangkan atau menunda kehamilan.

\section{DAFTAR PUSTAKA}

1. Prawiro Hardjo, Sarwono. Ilmu Kebidanan. Jakarta: PT. Bina Pustaka Sarwono Prawirihardjo;2009

2. Morgan, Geri. Obstetric dan Ginekologi Panduan Praktik. Jakarta: EGC;2009.

3. Bandiyah, Siti. Kehamilan, Persalinan, dan Gangguan Kehamilan. Yogyakarta: PT. Nuha Medika; 2009.

4. Notoatmodjo. Metodologi Penelitian Kesehatan.Jakarta : Rineka Cipta; 2005

5. Notoatmodjo. Metodologi Penelitian Kesehatan, Jakarta : Rineka Cipta; 2010

6. Salmah. Asuhan Kebidanan Antenatal. Jakarta: EGC;2006.

7. Purwaningsih, Wahyu. Asuhan Keperawatan Maternitas. Yogyakarta: PT. Nuha Medika; 2010.

8. Bari Saifuddin, Abdul. Buku Acuan Nasional Pelayanan Kesehatan Maternal dan Neonatal. Jakarta: PT. Bina Pustaka Sarwono Prawirohardjo;2006. 
9. Iqbal Mubarak, Wahit. Promosi Kesehatan Untuk Kebidanan. Jakarta: PT. Salemba Medika; 2011. 